\title{
The evolution of a mountain road network from its original use during the First World War to meeting today's forestry needs: current management
}

\author{
Raffaele Cavalli, Stefano Grigolato, Marco Pellegrini \\ Forest Operation Management Unit, Department of Land, Environment, Agriculture and Forestry, \\ University of Padova, Legnaro (PD), Italy
}

\begin{abstract}
In some mountain areas of northeastern Italy, the present forest road network has been partially developed using the previous military road network built during the First World War (WW I). The current management of the areas of forest considers the road network essential to provide access for forestry activities, but also to increase the value of recreational activities and tourism related to the historical importance of this area. The aim of the study was to investigate the technical evolution of a mountain road network from the beginning of the last century to today. The research consisted in a preliminary reconnaissance of the original road network using the WW I military maps, a further reconnaissance using the technical maps dated to the 1960 s, and the survey of the current road network through the differential global positioning system (D-GPS). The study also aimed to evaluate the current condition of the original road network according to the use made of it today in order to highlight how building standards influenced its evolution in terms of transportation systems and traffic management.
\end{abstract}

Correspondence: Stefano Grigolato, Forest Operation Management Unit, Department of Land, Environment, Agriculture and Forestry, University of Padova, viale dell'Università 16, 35020 Legnaro (PD), Italy.

E-mail: stefano.grigolato@unipd.it

Key words: road network, mountainous areas, historical roads, First World War.

Acknowledgements: the Authors express their gratitude to the Director of the Istituto Storico e di Cultura dell'Arma del Genio in Rome for allowing them to consult the historical documentation used in this work. Our special thanks to Dr. Lambiase from the same institute for his support and advice.

Received for publication: 5 July 2012 .

Accepted for publication: 21 November 2012.

(C) Copyright R. Cavalli et al., 2012

Licensee PAGEPress, Italy

Journal of Agricultural Engineering 2012; XLIII:e19

doi:10.4081/jae.2012.e19

This article is distributed under the terms of the Creative Commons Attribution Noncommercial License (by-nc 3.0) which permits any noncommercial use, distribution, and reproduction in any medium, provided the original author(s) and source are credited.

\section{Introduction}

Forest management today has to meet numerous objectives. The planning of multi-functional forest road networks is essential to meeting the aims of sustainable forest management (Gumus et al., 2008).

When wood harvesting is considered the principal economic benefit, the planning of forest road networks has to ensure the efficiency both of the operation itself and of the wood transportation (Klč, 2005). Forest road network parameters change according to construction location requirement and management activities. Furthermore, forest roads also bring together in a wider sense all those activities directly or indirectly related to the movement of goods, people and materials (Sudenberg and Silversides, 1988).

The ways in which forest access roads in mountain areas have been used and managed have been substantially modified over time. In the Italian Alps, the forest road networks are frequently the consequence of a historical combination of different requirements for mountain access. In this area, one of the most significant moments in the expansion of access to mountainous areas was just before and during the First World War (WW I). In fact, due to the lack of transportation infrastructures, the armies of those countries bordering the Alpine regions were forced to design and build a vast mountain road network for troop displacement and supplies; cable-car systems were only used in very steep areas.

Such was the great care taken to ensure that the technical features incorporated in these road networks and the materials used were suitable for the terrain, that most of the roads are still open today and are mainly used for forestry purposes (Boglione, 1998).

The purpose of this study is to use historical maps, geographical information system (GIS) analysis and field surveys to investigate how a transport network in a mountainous forest area has improved from the beginning of WW I to today, and to evaluate the condition of the original transport network according to its re-engineered condition and its current use.

\section{Materials and methods}

\section{Study area}

Study areas are located in the Altopiano dei Sette Comuni in the

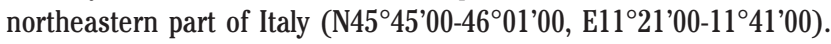
It represents a significant case study to analyze the expansion of the transport network from WW I to the present day (Cavalli et al., 2011). Two forest areas were identified: Boscon and Verena. The main difference between them was the average slope of the terrain while they had the same extent of forest area and almost the same area managed through the Forest Management Plans (Table 1). 
At the beginning of WW I, both areas were controlled by the Royal Italian Army. Two important Italian fortresses were located in the Verena area and the transport network was designed mainly to provide logistical access to them. The roads that were built were steep in order to provide the shortest route possible to reach the fortresses. The Boscon area remained in Italian possession for the whole of WW I while the Verena area was occupied by the Austro-Hungarian Army from May 1916 until the end of the war, and during this period the transport network was improved.

\section{Current extension of the road network}

The road network in these two areas developed differently over time and their layout over the terrain is also different. The geographical patterns of roads in forest landscapes can differ substantially from place to place, with commensurate differences in operational level (Cavalli and
Grigolato, 2010). Nevertheless, few technical details are known about how far the forest read network extends, even excluding those roads mainly used by the public that are fully described in the regional public road database. For these reasons, the current forest road network of the two areas was surveyed between 2010 and 2011 (155 km in the Boscon area and $102 \mathrm{~km}$ in the Verena area) using a professional differential global positioning system (D-GPS) (Trimble Pathfinder ProXH) (WGS 84 UTM $32 \mathrm{~N}$ ) and by post-processing the acquired data in order to obtain precise positions. Therefore, each road segment was classified according to its current main use (Table 2) and operative level (Table 3).

\section{Historical maps}

The evolution of the road network from its original military use to its forestry use and its current management was based on: i) initial period as shown by historical WW I maps (Carta d'Italia, up-graded during the

Table 1. Main characteristics of the two study areas.

\begin{tabular}{lcccccccc} 
Study area & A & FA & MF & PA & AT & MIT & Terrain slope & \% (mean) \\
& ha & $\%$ & $\%$ & \% MF & m a.s.l. & - & (SD) \\
Verena & 5776 & 86.7 & 80.8 & 75 & 1430 & Spruce and fir & 40.3 & 14.26 \\
Boscon & 3372 & 86.8 & 86.8 & 90 & 1250 & Spruce and beech & 28.8 & 31.37 \\
\hline
\end{tabular}

A, area; FA, covered by forest; MF, managed forest; PA, productive area; AT, altitude; $m$ a.s.l., meters above sea level; MT, main tree species; SD, standard deviation.

Table 2. Current road classification according to use.

\begin{tabular}{lll} 
Class & Functional classification & Main road use \\
O & Ordinary roads & National and regional major roads generally not used for forestry purposes \\
C & Access roads & Principal roads and roads rarely used for forestry purposes \\
\hline MF & Multi-function roads & Secondary roads with free access commonly used for rural, forestry or recreational purposes \\
FOR & Forest roads & Forest roads with free or restricted access for forestry purposes \\
\hline NC & Not classified & Network of temporary skid roads or trails not suitable for vehicles, including recreational trails \\
\hline
\end{tabular}

Table 3. Current road classification according to upper limit transportation system and standard layout.

\begin{tabular}{|c|c|c|c|c|c|}
\hline & Class & $\begin{array}{c}\text { Slope gradient } \\
\%\end{array}$ & $\begin{array}{l}\text { Width } \\
\mathrm{m}\end{array}$ & $\begin{array}{c}\text { Curve radius } \\
\mathrm{m}\end{array}$ & $\begin{array}{c}\text { Upper limit } \\
\text { transportation system }\end{array}$ \\
\hline 1 & Low mobility and high-load capacity & $3.0-8.0(\max 14)$ & $5.0-6.0(\min 3.5)$ & 10 & Truck with trailer \\
\hline 2 & Low mobility and medium (+) load capacity & $3.0-8.0(\max 18)$ & $4.0-5.0(\min 3.0)$ & 7 & Truck \\
\hline 3 & High mobility and medium (-) load capacity & $3.0-8.0(\max 25)$ & $3.0-4.0(\min 3.0)$ & 7 & Forwarder or tractor with forest trailer \\
\hline 4 & High mobility and low or null load capacity & $5.0-10.0(\max 25)$ & $3.0-4.0(\min 2.5)$ & 5 & Small tractor with single axle carriage \\
\hline 0 & \multicolumn{5}{|c|}{ Temporary skid roads or trail not suitable for vehicles } \\
\hline
\end{tabular}

Table 4. List of the collected and georeferenced historical maps for military use.

\begin{tabular}{|c|c|c|c|c|c|}
\hline Code & Map & Scale & First survey & General reconnaissance & Upgrade (date) \\
\hline Conco & Sheet 37 Carta d'Italia Sez. III N.E. & $1: 25,000$ & 1887 & 1910 & 15.8.1917 \\
\hline Valstagna & Sheet 37 Carta d'Italia Sez. IV S.E. & $1: 25,000$ & 1886 & 1910 & 15.8.1917 \\
\hline Asiago & Sheet 37 Carta d'Italia Sez. IV S.O. & $1: 25,000$ & 1886 & - & - \\
\hline Monte Lisser & Sheet 37 Carta d'Italia Sez. IV N.E. & $1: 25,000$ & 1886 & - & 15.8.1917 \\
\hline Cima Dodici & Sheet 37 Carta d'Italia Sez. IV N.O. & $1: 25,000$ & - & 1910 & 15.8.1917 \\
\hline Monte Verena & Sheet 36 Carta d'Italia Sez. I N.E . & $1: 25,000$ & - & - & 15.8.1917 \\
\hline Rotzo & Sheet 36 Carta d'Italia Sez. I S.E. & $1: 25,000$ & 1886 & 1912 & 15.8.1917 \\
\hline Caltrano & Sheet 36 Carta d'Italia Sez. III N.O. & $1: 25,000$ & 1887 & - & 15.8.1917 \\
\hline Arsiero & Sheet 36 Carta d'Italia Sez. II N.E. & $1: 25,000$ & 1886 & 1912 & 31.5.1917 \\
\hline
\end{tabular}

Sez., section. 
WW I for military use); ii) intermediate period as confirmed by historical aerial-photographs (Italian Aeronautic Group material dated 1954$55)$; iii) current period as reported by GPS survey (2010-11).

In order to analyze the evolution of the road network in the two study areas, we explored the availability of historical maps and aerial-photographs. To guarantee the standardization of the data, we considered using historical maps with the same scale, the same revision time and of the same origin. Initial research identified 9 historical maps of the map of Italy (Carta d'Italia) up-graded during WW I for military use (IGM, 1886, 1917) and these were collected from the Biblioteca Civica Bertoliana, Vicenza, north-eastern Italy (Table 4).

The collected maps reported a considerable number of geographical features and, in particular, gave a precise and detailed description of features of the transport network. Roads are categorized in 4 main operative classes; permanent trails adapted for haulage by mules (mulattiera) are also reported.

A simple explanatory categorization of the road transportation network during WW I in mountainous conditions similar to those of the Altopiano dei Sette Comuni is reported by Sigurtà (2002) that indicates camionabili as truck roads (generally over $4.0 \mathrm{~m}$ wide and a less than $10 \%$ gradient) and the carrozzabili as roads adapted for tractors with trailer (2.50-4.0 m wide and a less than $10 \%$ gradient). Sigurtà also describes the mulattiera which varies between 1.5-2.5 $\mathrm{m}$ in width with an over 10\% gradient (max. 28-30\%). Boglione (2008) reports that, in mountainous areas, the camionabili and carrozzabili roads also have short sections with gradients of over 10\% (max. 12-14\%). The maps were scanned to obtain digital images. The scanned maps were then aligned and georeferenced in WGS 84 UTM $32 \mathrm{~N}$ and then grouped in a single dataset.

In order to verify the condition of the forest road network at an intermediate state, historical aerial-photographs of the Italian Aeronautic Group (GAI) dating from 1954-55 (AA.VV., 2011) were collected and grouped in a single dataset. The GAI aerial-photographs were scanned at $600 \mathrm{dpi}$ resolution to be adapted to an application scale of $1: 10,000$ (Savio, 2011).

The two datasets concerning the maps of the Carta d'Italia for military use and the GAI aerial-photographs were then up-loaded into a single geodatabase (Figure 1).

\section{Extraction of the historical transport network}

The transport network on the 1917 historical maps was digitalized in vector format. For each transport network segment (identified as the road segment between two nodes of the road network), the class, the width, the gradient and the presence of walls, bottlenecks and extra widths (such as landings, switchback area and square) were reported according to the legend and the technical notes reported in the maps (Table 5).

As a first step, the digitalization considered the same layout shown by the maps. Since the horizontal layout of the transport segments of the maps was not always reliable (because of the accuracy of the historical maps), a second step took into account the alignment of the digitalized segment to the current road network previously surveyed by the D-GPS.

The alignment considered integration of the information of the historical road network to the current road network. The integration was evaluated only where the segments in the maps clearly overlapped (within a buffer of $30 \mathrm{~m}$, corresponding to $12 \mathrm{~mm}$ on the map at a scale of $1: 25,000$ ) the segment surveyed by the D-GPS. Where the historical road network differed (approximately 33\%) in terms of horizontal layout, and outside the buffer area of $30 \mathrm{~m}$, the road network was considered different from the current network alignment and for this reason was not integrated to the dataset of the current road network.

In order to verify the maps of the Carta d'Italia for military use, and to obtain more information about the standard construction and the road design for mapped roads, the original road construction projects and the road maintenance plans of the Alpine Troop Command (Comando Truppe Altipiano) and the Italian $6^{\text {th }}$ Army ( $6^{\text {th }}$ Armata) were examined. The data were retrieved from the collection of historical documents at the Museum of the Institute of the History and Culture of the Engineer Corps (ISCAG, 1916, 1917a, 1917b) in Rome. The data collected were up-loaded into the geodatabase.

As a consequence, the forest road network shown in the GAI aerialphotographs was digitalized and then integrated into the current road network according to methods applied described above. The final geodatabase covered each segment of the current road network in three periods: 1915-1918, 1953-1954, 2010-2011.

All GIS operations, dataset management and analyses were supported by ArcGIS 10 software (ESRI, 2010) while Statistic software SPSS Release 18 (SPSS Inc., IBM Company, Chicago, IL, USA) was used for statistical analysis.

\section{Field survey plan}

We analyzed current road segments overlapping the historical transportation network in the first period (WW I). The main features analyzed were the deterioration of the artifacts and the re-engineered condition of the historical transportation network. The surveys were carried out to cover all the road classes included in the legend of the historical Carta d'Italia. The survey plan had been previously randomly extracted with the support of the GIS analysis by considering one survey point every $0.5 \mathrm{~km}$ of the historical road network.

The field procedure considered the collection of different parameters and information within $25 \mathrm{~m}$ segments. Length and slope gradients were measured by a laser rangefinder with an integrated compass, and an inclinometer allowed us to measure straight stretches of road (5-400 $\mathrm{m})$. A standard measuring tape was used for distances under $5 \mathrm{~m}$.

Table 5. Transport network classification of the Carta d'Italia for military use during World War I.

\begin{tabular}{lccc} 
Class & $\begin{array}{c}\text { Width } \\
\text { m }\end{array}$ & $\begin{array}{c}\text { Road gradient } \\
\%\end{array}$ & Other features \\
& $>8$ & $<7 ; 7-12 ;>12$ & Wall; bottlenecks and extra width \\
1 & $6-8$ & $<7 ; 7-12 ;>12$ & Wall; bottlenecks and extra width \\
\hline 3 & $<6$ & $<7 ; 7-12 ;>12$ & Wall; bottlenecks and extra width \\
4 & Not indicated & Not specified & Wall; bottlenecks and extra width \\
\hline mulattiera & Not indicated & Not specified & Not specified \\
\hline
\end{tabular}

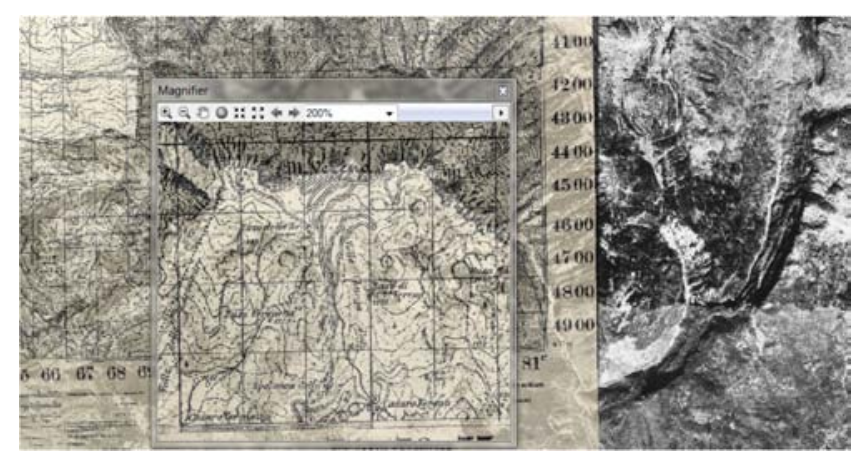

Figure 1. Map composed from enlargement of the Carta d'Italia and Italian Aeronautic Group aerial-photographs integrated in a single geodatabase. 
Table 6. The extension of the road network between World War I to 2010-2011.

\begin{tabular}{|c|c|c|c|c|c|c|c|c|}
\hline \multirow{3}{*}{ Area } & \multirow{2}{*}{\multicolumn{2}{|c|}{$\begin{array}{c}\text { World War I } \\
\text { A }\end{array}$}} & \multirow{2}{*}{\multicolumn{3}{|c|}{ 1953-1954 }} & \multicolumn{3}{|c|}{$2010-2011$} \\
\hline & & & & \multicolumn{2}{|c|}{$\Delta \mathrm{AB}$} & \multirow{2}{*}{$\begin{array}{c}\mathrm{C} \\
\mathrm{km}\end{array}$} & \multicolumn{2}{|c|}{$\Delta \mathrm{AC}$} \\
\hline & km & $\mathrm{m} \mathrm{ha} \mathrm{a}^{-1}$ & $\begin{array}{l}B \\
\mathrm{~km}\end{array}$ & $\mathrm{~km}$ & $\mathrm{~m} \mathrm{ha}^{-1}$ & & km & $\mathrm{m} \mathrm{ha} \mathbf{a}^{-1}$ \\
\hline Verena & 69.8 & 12.1 & 105.9 & 36.1 & 18.3 & 155.4 & 85.6 & 26.9 \\
\hline Boscon & 44.1 & 13.1 & 90.6 & 46.5 & 26.9 & 102.2 & 58.1 & 30.3 \\
\hline Total & 113.9 & 12.5 & 196.5 & 82.6 & 21.5 & 257.6 & 143.7 & 28.2 \\
\hline
\end{tabular}

The survey included qualitative and quantitative features for each road segment:

- width: the current average running surface, including shoulders and carriageway (m);

- gradient: the current road gradient (\%);

- current condition compared to the standard WW I layout: completely re-engineered, partially re-engineered, partially preserved, completely preserved;

- historical artifacts: retaining walls, drainage systems (such as cambers, culverts, ditches or cross drain), and bridges;

- historical artifact deterioration: high, medium, low, not evaluable;

- road surface: current road surface (asphalt, gravel or natural);

- current access: reporting road traffic limitations and use.

\section{Results and discussion}

\section{The road network from the First World War to today}

The data obtained from the digitalization of the historical maps of the WW I and from the digitalization of the GAI aerial-photographs indicated a considerable increase $(+126 \%)$ of the extension of the road network extracted from the WW I Carta d'Italia maps (113.9 km) to today $(257.6 \mathrm{~km})$ (Table 6$)$.

We included the Class 3 and Class 4 road networks of WW I since the legend of the Carta d'Italia detailed them as suitable for vehicles, in contrast to the mulattiera that were not suitable and were, therefore, not taken into consideration.

By comparing the extension of the road network (including forest, pasture and grassland areas) from WW I to today, the road network density in the Verena area increased from $12.1 \mathrm{~m} \mathrm{ha}^{-1}$ to $26.9 \mathrm{~m} \mathrm{ha}^{-1}$, while in the Boscon area, road network density increased from $13.1 \mathrm{~m} \mathrm{ha}^{-1}$ to $30.3 \mathrm{~m} \mathrm{ha}^{-1}$.

Table 7 reports the extension of the current road network as classified according to operative level. Table 8 shows the WW I road network extension according to the operative classification indicated in the legend of the Carta d'Italia.

\section{The original alignment of the First World War transport network}

As detailed in Table 8, the WW I road network within the study areas was composed of only Class 3 and Class 4 roads and mulattiera. According to the legend of the Carta d'Italia, it is evident that the roads were generally no more than $6 \mathrm{~m}$ wide (including shoulders and carriageway) and the mulattiera represented a considerable part of the WW I transportation network. This is similar to the condition of the military road network in mountain areas described by Boglione (2008) in northwestern Italy and by Sigurtà (2002) in northern-central Italy.

The analysis verified the location of the transportation network according to the characteristics of the terrain surrounding each transport segment (a buffer of $50 \mathrm{~m}$ was considered for both the sides of the road segment). The analysis considered the steepness of the terrain
Table 7. Operative level of the current road network according to road classification as described in Table 3.

\begin{tabular}{|c|c|c|c|c|c|c|}
\hline \multirow{2}{*}{$\begin{array}{l}\text { Operative level } \\
\text { Class }\end{array}$} & \multicolumn{3}{|c|}{ Verena } & \multicolumn{3}{|c|}{ Boscon } \\
\hline & km & $\%$ & $\mathrm{~m} \mathrm{ha}^{-1}$ & km & $\%$ & $\mathrm{~m} \mathrm{ha}^{-1}$ \\
\hline 1 & 12.8 & 8.2 & 2.2 & 7.3 & 7.1 & 2.2 \\
\hline 2 & 26.2 & 16.9 & 4.5 & 42.1 & 41.2 & 12.5 \\
\hline 3 & 67.2 & 43.3 & 11.6 & 31.0 & 30.4 & 9.2 \\
\hline 4 & 49.2 & 31.7 & 8.5 & 21.8 & 21.4 & 6.5 \\
\hline Total & 155.4 & 100 & 26.9 & 102.2 & 100 & 30.3 \\
\hline
\end{tabular}

Table 8. Operative level of World War I transport network as described in Table 5.

\begin{tabular}{lcccccc}
$\begin{array}{l}\text { Operative level } \\
\text { Class }\end{array}$ & \multicolumn{3}{c}{ Verena } & \multicolumn{3}{c}{$\begin{array}{c}\text { Boscon } \\
\%\end{array}$} \\
\hline 3 & 39.5 & 32.6 & 6.8 & 35.1 & 51.0 & 10.4 \\
4 & 30.3 & 25.0 & 5.2 & 9.0 & 13.1 & 2.7 \\
\hline mulattiera & 51.3 & 42.4 & 8.9 & 24.7 & 35.9 & 7.3 \\
Total & 121.1 & 100 & 21.0 & 68.8 & 100 & 20.4 \\
\hline
\end{tabular}

(or terrain slope) as a percentage. The terrain slope was calculated by a Digital Terrain Model with a resolution of $5 \times 5 \mathrm{~m}$. At this resolution, the morphology of the terrain was considered constant for the entire period from WW I to the situation today. According to this approach, the results highlighted that in the Verena area the WW I transportation network (135 segments with an average steepness of the surrounding terrain of $30.95 \%$ ) was located in terrain steeper than in the Boscon area (102 segments with an average steepness of the surrounding terrain of 22.17\%). The two means were, therefore, compared by Mann-Whitney non-parametric test with the null hypothesis that the two means were equal. The result reported $\mathrm{P}=0.000$, justifying the rejection of the null hypothesis. Therefore, a total of 237 segments were extracted and analyzed in terms of road gradient. The road gradient was determined by considering the difference between the start and the end vertex of each segment and the length of the same segment. The procedure was based on a semiautomatic method developed in ArcGIS 10. Data obtained on the gradient of each transportation network segment showed an average gradient of $5.93 \%$ for the Boscon area and of $8.62 \%$ for the Verena area. The Independent-Samples t-test was applied to test the significance of the difference between the two means with a $95 \%$ confidence interval (CI) The t-test reported $\mathrm{P}=0.000$, justifying the rejection of the null hypothesis that the two means were equal.

The one-way analysis of variance (ANOVA) procedure was then used to compare the means of the road gradient for the three groups: Class 3, Class 4 and mulattiera. As the Levene statistical test confirmed the null hypothesis that the group variances were equal, the pairwise multiple 
Table 9. Least significant difference test on the means of the road gradient for the three historical transportation classes.

\begin{tabular}{|c|c|c|c|c|c|c|}
\hline Wh & lass & Mean difference & SE & $\mathbf{P}$ & Confi & erval 95\% \\
\hline $\mathbf{A}$ & B & $(A-B)$ & & & Lower bound & Upper bound \\
\hline 3 & 4 & -0.965 & 0.987 & 0.329 & -2.91 & 0.98 \\
\hline & mulattiera* & -4.259 & 0.812 & 0.000 & -5.86 & -2.66 \\
\hline 4 & 3 & 0.965 & 0.987 & 0.329 & -0.98 & 2.91 \\
\hline & mulattiera* & -3.294 & 1.013 & 0.001 & -5.29 & -1.30 \\
\hline mulattiera & $3^{*}$ & 4.259 & 0.812 & 0.000 & 2.66 & 5.86 \\
\hline & $4^{*}$ & 3.294 & 1.013 & 0.001 & 1.30 & 5.29 \\
\hline
\end{tabular}

*Mean difference is significant at $\mathrm{P}=0.05$. SE, standard error; $\mathrm{WW}$ I, First World War.

comparisons were based on the least significant difference (LSD) test. The main results of this statistical analysis are reported in Table 9 . We can see that the mulattiera was the part of the WW I transportation network with the highest road gradient: an average $10.0 \%$, maximum 23.8\%. The Class 3 and Class 4 road segments included showed an average road gradient of $5.75 \%$ and $6.72 \%$ with a maximum value of $18.8 \%$ and $18.9 \%$, respectively.

\section{The current alignment of the First World War transport network still in use}

A total of $80.5 \mathrm{~km}$ of the current road network overlapped the WW I transportation network, i.e. approximately $31.3 \%$ of the existing road networks. Therefore, the current alignment of the WW I transport network still in use as a forest road network was analyzed in terms of carriageways and gradient (Table 10) by considering the data collected by GPS during 2010 and 2011.

The road network analyzed was composed of 87 segments grouped according to their original classification as reported in the Carta d'Italia. The resulting means for the carriageways and the road gradient are reported in Table 11.

One-way ANOVA was used to compare the means of the carriageway and the road gradient between the three road classification groups (Class 3, Class 4 and mulattiera) of the Carta d'Italia. The pairwise multiple comparisons were based on the LSD test for the evaluation of the means of carriageway, as the Levene statistical test confirmed the null hypothesis that the variances of the three groups were equal (Table 12). For the road gradient, the Levene statistical test did not confirm the null hypothesis that the group variances were equal and for this reason the Tamhane T2 test was applied (Table 13).

As can be seen from Table 12, the Class 3 reported significantly larger carriageways than Class 4 and mulattiera; alternatively, the statistical analysis indicated that the means of the carriageways of Class 4 and mulattiera are equal.

As indicated in Table 13, the means of the road gradient of all the groups are equal. As far as the mulattiera are concerned, it could be suggested that only the mulattiera that have been re-designed with a gradient suitable for vehicles are part (10.8\%) of today's road networks.

\section{The remaining artifacts of the historical transportation network}

The current state of the WW I transportation network was evaluated through a survey of 145 control points along the current road network. Thirty-six percent of the control points were collected on roads originally WW I Class 3, 48\% on roads originally Class 4, and the remaining $16 \%$ on roads originally WW I mulattiera.

The results show that a great number of road segments originally
Table 10. Extension of the World War I transport network still in use as forest road network.

\begin{tabular}{lccccccc}
$\begin{array}{l}\text { Operative level } \\
\text { WW I transportation class }\end{array}$ & \multicolumn{3}{c}{ Verena } & \multicolumn{3}{c}{ Boscon } \\
\hline 3 & 25.4 & 62.1 & 7.5 & 19.5 & 49.0 & 3.4 \\
\hline 3 & 6.3 & 15.5 & 1.9 & 16.3 & 41.2 & 2.8 \\
\hline mulattiera & 9.1 & 22.4 & 2.7 & 3.9 & 9.8 & 0.7 \\
Total & 40.8 & 100 & 12.1 & 39.7 & 100 & 6.9 \\
\hline
\end{tabular}

WW I, First World War.

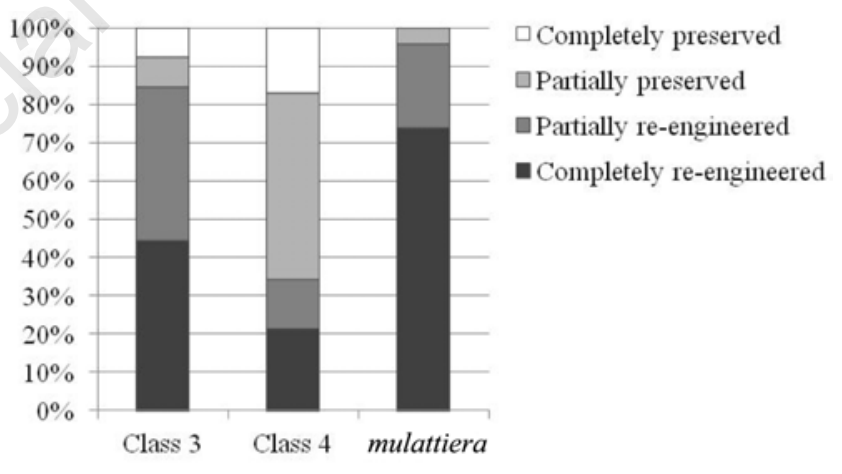

Figure 2. Upgrading of the historical transportation network according to the transportation classes reported in the Carta d'Italia.

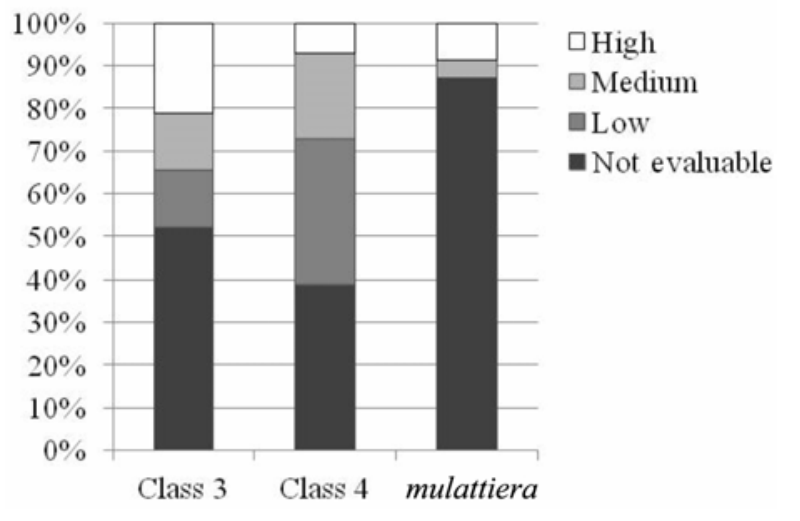

Figure 3. Deterioration of the alignment and artifacts of the World War I transportation network. 
classified as Class 3 (Carta d'Italia classification) are currently adapted to vehicles with low mobility and high-load capacity (corresponding to Class 1 and Class 2 of the current operational classification reported on Table 3) (Table 14). The results also show that the mulattiera has often been re-engineered to the current operational Class 2 and Class 3 , while the road segments originally classified as Class 4 have been adapted to a high mobility and medium-low load capacity or to a high mobility and a low or null load capacity (corresponding to the current Class 3 and Class 4 in the operational classification reported in Table 3). As shown in Figure 2, mulattiera have mostly been completely re-engineered in their horizontal and gradient alignment. Where they could still be evaluated, the mulattiera and the Class 3 roads (according to the Carta d'Italia classification) showed appreciably high deterioration of the historical artifacts (Figure 3).

Table 11. Descriptive statistic for the carriageway and the road gradient of the World War I transport network still in use as forest road network.

\begin{tabular}{|c|c|c|c|c|c|c|c|c|c|}
\hline Variable & Group (Class) & No. & Mean & SD & SE & Co & l $95 \%$ & Min & Max \\
\hline & & & & & & Lower bound & Upper bound & & \\
\hline CW (m) & 3 & 46 & 3.6 & 0.660 & 0.097 & 3.4 & 3.8 & 2.5 & 5.0 \\
\hline & 4 & 22 & 2.8 & 0.527 & 0.112 & 2.6 & 3.0 & 2.0 & 4.0 \\
\hline & mulattiera & 19 & 3.1 & 0.762 & 0.175 & 2.7 & 3.4 & 2.0 & 4.0 \\
\hline & All & 87 & 3.3 & 0.746 & 0.080 & 3.1 & 3.5 & 2.0 & 5.0 \\
\hline VG (\%) & 3 & 46 & 4.3 & 3.300 & 0.487 & 3.3 & 5.3 & 0.0 & 10.3 \\
\hline & 4 & 22 & 5.2 & 3.540 & 0.755 & 3.6 & 6.8 & 0.0 & 10.3 \\
\hline & mulattiera & 19 & 6.6 & 5.450 & 1.250 & 4.0 & 9.2 & 0.0 & 16.2 \\
\hline & All & 87 & 5.0 & 3.974 & 0.426 & 4.2 & 5.9 & 0.0 & 16.2 \\
\hline
\end{tabular}

SD, standard deviation; SE, standard error; CW, carriageway; VG, road gradient.

Table 12. Least significant difference test on the means of the carriageway.

\begin{tabular}{|c|c|c|c|c|c|c|}
\hline G & & Mean difference & SE & P & Confic & l $95 \%$ \\
\hline A & B & $(A-B)$ & & & Lower bound & Upper bound \\
\hline 3 & $\begin{array}{c}4^{*} \\
\text { mulattiera* }\end{array}$ & $\begin{array}{l}0.842 \\
0.584\end{array}$ & $\begin{array}{l}0.170 \\
0.178\end{array}$ & $\begin{array}{l}0.000 \\
0.002\end{array}$ & $\begin{array}{l}0.504 \\
0.230\end{array}$ & $\begin{array}{l}1.179 \\
0.939\end{array}$ \\
\hline 4 & $\begin{array}{c}3^{*} \\
\text { mulattiera }\end{array}$ & $\begin{array}{l}-0.842 \\
-0.257\end{array}$ & $\begin{array}{l}0.170 \\
0.205\end{array}$ & $\begin{array}{l}0.000 \\
0.213\end{array}$ & $\begin{array}{l}-1.179 \\
-0.664\end{array}$ & $\begin{array}{c}-0.504 \\
0.150\end{array}$ \\
\hline mulattiera & $\begin{array}{c}3^{*} \\
4\end{array}$ & $\begin{array}{c}-0.584 \\
0.257\end{array}$ & $\begin{array}{l}0.178 \\
0.205\end{array}$ & $\begin{array}{l}0.002 \\
0.213\end{array}$ & $\begin{array}{l}-0.939 \\
-0.150\end{array}$ & $\begin{array}{c}-0.230 \\
0.664\end{array}$ \\
\hline
\end{tabular}

*Mean difference is significant at $\mathrm{P}=0.05$. $\mathrm{SE}$, standard error.

Table 13. Tamhane T2 test on the means of the carriageway.

\begin{tabular}{ccccccc} 
A Group (Class) & B & $\begin{array}{c}\text { Mean difference } \\
(\mathbf{A}-\mathbf{B})\end{array}$ & SE & P & \multicolumn{2}{c}{$\begin{array}{c}\text { Confidence interval 95\% } \\
\text { Upper bound }\end{array}$} \\
\multirow{2}{*}{3} & 4 & -0.875 & 0.898 & 0.707 & -3.115 & 1.366 \\
& mulattiera & -2.270 & 1.342 & 0.280 & -5.717 & 1.177 \\
4 & 3 & 0.875 & 0.898 & 0.707 & -1.366 & 3.115 \\
& mulattiera & -1.395 & 1.461 & 0.722 & -5.088 & 2.297 \\
\hline mulattiera & 3 & 2.270 & 1.342 & 0.280 & -1.177 & 5.717 \\
& 4 & 1.395 & 1.461 & 0.722 & -2.297 & 5.088 \\
\hline
\end{tabular}

SE, standard error.

Table 14. Current operational classification of the World War I transportation network.

\begin{tabular}{lccccc} 
WW I operational classification (see Table 5) & \multicolumn{3}{c}{$\begin{array}{c}\text { Current operational classification (see Table 3) } \\
\text { Class } 3\end{array}$} & Class 4 \\
Class 3 & $7.7 \%$ & $55.8 \%$ & $32.7 \%$ & $3.8 \%$ & \\
Class 4 & - & $10.0 \%$ & $67.1 \%$ & $2.9 \%$ \\
\hline mulattiera & - & $56.5 \%$ & $43.5 \%$ & - \\
\hline
\end{tabular}

WW I, First World War. 


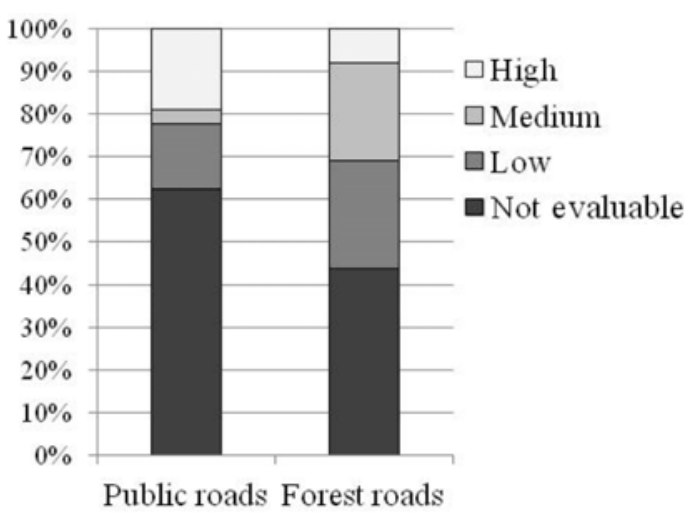

Figure 4. Upgrading of the World War I transportation network according to current traffic limitations.

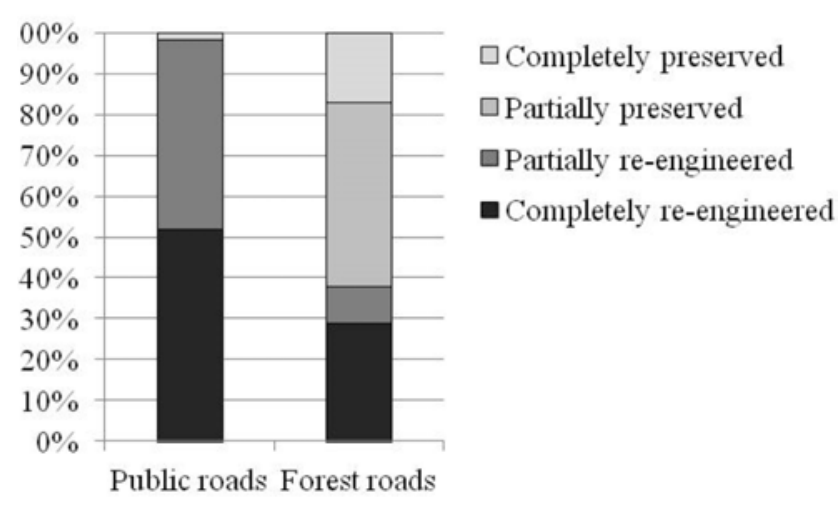

Figure 5. Deterioration of the alignment and artifacts in relation to current traffic limitations.

Furthermore, the current roads closed to ordinary traffic (forest roads) are the best-preserved in term of the original alignment and artifacts, while the current forest roads open to ordinary traffic (public roads) are the most up-graded and re-engineered with respect to their origin (Figure 4). For both groups, $50 \%$ of the artifacts clearly show a high or medium deterioration (Figure 5).

\section{Conclusions}

The purpose of this study was to investigate the improvement of the transport network from the beginning of the First World War to today's road network in mountainous forest areas.

The first results for the two areas selected in the Altopiano dei Sette Comuni confirmed that an appreciable part (68\%) of the original WW I transportation network is still in use. Part of the network has been totally re-engineered (generally with a wider carriageway and a lower road gradient) in order to safely support ordinary traffic related to agriculture and forestry activities, and nowadays also for both summer and winter recreational activities. In fact, most of the re-engineered road segments have been asphalted, and now have larger shoulders and protective barriers as safety features to ensure drivers do not go off the roads. Part of the network has only been partially preserved because it is only used for servicing forestry or quarrying activities.

Future projects include the use of LiDAR-Light Detection And Ranging, a remote sensing technique combined with statistical analysis and mathematical modeling. The LiDAR technique is able to unmask many hidden features such as unused roads, trails and other historical features in a woodland landscape (Crow, 2009; Pirotti et al., 2012) and its use will promote greater accuracy of the survey and a more detailed analysis of the road network.

\section{References}

AA.VV. 2011. L'evoluzione dei boschi veneti. Analisi delle dinamiche spaziali dei popolamenti forestali regionali. Regione del Veneto, Unità di Progetto Foreste Parchi, Venezia-Mestre, p 174.

Boglione M. 2008. Le strade dei cannoni. Blu edizioni, Torino, p 254.

Cavalli R., Grigolato S. 2010. Influence of characteristics and extension of a forest road network on the supply cost of forest woodchips. J. For. Res. 15:202-9.

Cavalli R., Pellegrini M., Grigolato S., Bietresato M. 2011. A strategy for the management of abandoned mountain pasture lands colonised by dwarf pine. Italian J. Forest Mountain Environ. 66: 383-93.

Crow P. 2009. Landscapes and LiDAR: history under the greenwood tree. Significance 6:58-62.

ESRI 2010. ArcGIS 10-ArcInfo. Environmental System Research Institute, Redland, CA, USA.

Gumus S., Akar H.H., Toksoy D. 2008. Functional forest road network planning by consideration of environmental impact assessment for wood harvesting. Environ. Monit. Assess. 142:109-16.

ISCAG (Istituto Storico e di Cultura dell'Arma del Genio). 1916. Comando Generale Genio - Truppe Altipiano - Relazione Comunicazioni e specchi relativi alla manutenzione stradale e ponti, Armadio 1, Contenitore 54, Cartella 5. Authorization No. 19474, 15.6.2011.

ISCAG (Istituto Storico e di Cultura dell'Arma del Genio). 1917a. Comando Generale Genio - 6a Armata, Mappa Asiago Sud Zona 1, Armadio 1, Contenitore 55. Authorization No. 19474, 15.6.2011.

ISCAG (Istituto Storico e di Cultura dell'Arma del Genio). 1917b.

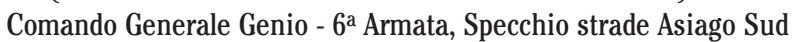
zona 1, Armadio 1, Contenitore 55. Authorization No. 19474, 15.6.2011.

IGM (Istituto Geografico Militare). 1886. Foglio 37 Carta d'Italia Sez. IV S.0. 1:25000. Istituto Geografico Militare, Firenze.

IGM (Istituto Geografico Militare). 1917. Fogli 36-37 Carta d'Italia Sez. I-IV. 1:25000. Istituto Geografico Militare, Firenze.

Klč P. 2005. Research on principles of making access to mountain forests by forest roads network. J. For. Sci. 51:116-26.

Pirotti F., Grigolato S., Lingua E., Sitzia T., Tarolli P. 2012. Laser Scanner Applications in Forest and Environmental Sciences. Italian J. Remote Sensing. 44:109-23.

Savio D. 2011. Tecniche object-oriented per l'estrazione delle coperture forestali da fotogrammi storici pancromatici. Italian J. Remote Sensing. 43:161-76

Sigurtà D. 2002. Catalogazione della viabilità militare storica nell'Alto Garda-Adamello. Degree diss., Politecnico Milano-Bovisa, Italy.

Sudenberg U., Silversides C.R. Operational efficiency in Forestry. Volume 1: Analysis. Kluwer Academic Publishers, Dordrecht, the Netherlands. 